Revista Brasileira de Agricultura Irrigada v.11, nº.5, p. 1677 - 1684, 2017

ISSN 1982-7679 (On-line)

Fortaleza, CE, INOVAGRI - http://www.inovagri.org.br

DOI: $10.7127 /$ rbai.v11n500747

Protocolo 747.17 - 23/05/2017 Aprovado em 31/08/2017

\title{
WATER USE IN IRRIGATED AGRICULTURE: AN APPROACH TO WATER PRODUCTIVITY IN DRIP AND SPRINKLER SYSTEMS
}

\author{
Fernanda Lamede Ferreira de Jesus ${ }^{1}$, Jéssica Garcia Nascimento ${ }^{2}$, Rubens Duarte Coelho ${ }^{3}$, \\ Sergio Nascimento Duarte ${ }^{4}$, Fernando Campos Mendonça ${ }^{5}$
}

\begin{abstract}
Irrigation plays an important role in agriculture and the increase in the irrigated area and scarce water resources have encouraged the use of irrigation systems and management systems that increase the efficiency of water use. Thus, maximize water productivity has been one of the most important challenges in agriculture. The present study aimed to relate information on water productivity for two irrigation systems, drip and sprinkler systems, with the purpose of understanding the characteristics of these systems and contributing to the advancement of studies and research carried out in the area. Technological innovations aimed at reducing consumption and increasing water productivity through improved water management practices have had limited impact and still need to be adopted on a large scale. It should be emphasized that future research and studies should focus on strengthening the relationships between yield and water consumption to improve productivity. In addition, the techniques and technologies to be deployed in the field must be preceded by a cost analysis for each specific situation in order to verify the economic viability of its adoption.
\end{abstract}

Keywords: Water resources, irrigation efficiency, water productivity.

\section{USO DA ÁGUA NA AGRICULTURA IRRIGADA: UMA ABORDAGEM SOBRE A PRODUTIVIDADE DA ÁGUA EM SISTEMAS DE GOTEJAMENTO E ASPERSÃO}

\section{RESUMO}

A irrigação desempenha um importante papel na agricultura e o aumento da área irrigada e a escassez de recursos hídricos têm fomentado o uso de sistemas de irrigação e sistemas de manejo que aumentam a eficiência do uso da água. Assim, o aumento da produtividade de água tem sido um dos desafios mais importantes na agricultura. O presente estudo objetivou

\footnotetext{
${ }^{1}$ Agricultural and Environmental Engineering, Doctor student in Agricultural Systems Engineering, ESALQ/USP, fernandalamede@usp.br

${ }^{2}$ Master student in Agricultural Systems Engineering, ESALQ/USP, jessicagarcia@usp.br

${ }^{3}$ Doctor professor, Department of Biosystems Engineering - ESALQ/USP, rdcoelho@usp.br

${ }^{4}$ Doctor professor, Department of Biosystems Engineering - ESALQ/USP, snduarte@usp.br

${ }^{5}$ Doctor professor, Department of Biosystems Engineering - ESALQ/USP, fernandomendonca@usp.br
} 
relacionar as informações sobre a produtividade da água em dois tipos de sistemas de irrigação, gotejamento e aspersão, com o propósito de facilitar a compreensão das características de ambos e contribuir com o avanço dos estudos e pesquisas realizadas na área. As inovações tecnológicas que visam à redução do consumo e o aumento da produtividade de água por meio de melhores práticas de gestão da mesma têm tido um impacto limitado e ainda precisam ser adotadas em larga escala. É oportuno salientar que pesquisas e estudos futuros devem focar o fortalecimento das relações entre rendimento e consumo de água para melhorar sua produtividade. Além disso, as técnicas e tecnologias a serem implantadas no campo devem ser precedidas de uma análise de custo para cada situação específica, a fim de verificar a viabilidade econômica de sua adoção.

Palavras-chave: Recursos hídricos, eficiência de irrigação, produtividade da água.

\section{INTRODUCTION}

Water is an essential natural resource to life on the planet and agricultural production. Its availability and quality are extremely relevant for the viability of the crop establishment, and their excess or scarcity can be considered as productivity limiting factors. The terms "water use efficiency" and "water productivity" are often used as synonyms to express the production per unit of water used (HOWELL, 1990; PERRY, 2007; KELLER; SECKLER, 2005; ZWART; BASTIAANSSEN, 2004). However, several authors define water productivity as crop yield per unit of water consumed (PERRY et al., 2009, YAN; WU, 2014), and efficiency as the act of obtaining the desired result with the minimum resources use, and is usually expressed as a percentage of the best possible result.

The increase of the irrigated area and water resources scarcity in several regions of Brazil and in the world have promoted the use of irrigation and management systems that aim to increase the water use efficiency. Therefore, increasing crop yields per unit of water used has been one of the most important challenges in agriculture (AHMAD et al., 2016, YAN; WU, 2014; PERRY, 2011). Irrigation is a highly attractive activity, but it is only profitable and sustainable when properly performed, through techniques that maximize the efficiency of land and water, promoting operational costs reduction and environmental impacts (LACERDA; OLIVEIRA, 2007). Water resources management at farm level includes the adoption of appropriate irrigation practices in order to water savings. If the irrigator aims to maximize productivity, irrigation management implies that the water needs of the crops must be fully met, but if the objective is to maximize water use efficiency, a controlled deficit irrigation technique can be adopted.

There are several techniques and various methods of irrigation, and the best method to use depends on several factors. There is no applicable or advantageous irrigation system in all circumstances (VIEIRA et al., 2011). Therefore, it is necessary technical knowledge, practical experience and common sense to choose the method and the most appropriate system in each situation at field level.

The pressurized irrigation systems include localized irrigation and sprinkler systems, and are good alternatives for many crops and areas. Drip irrigation performs the application, in small quantities, dripping water directly onto soil surface near the roots of the plants (COELHO et al., 2013). Sprinkler irrigation, however, launches water jets into the air that fall on crop canopy as raindrops (EMBRAPA, 2010).

The expansion of irrigation and its methods in Brazil was observed by Paulino et al. (2011), when analyzing the data of agricultural censuses conducted by IBGE from 1995/1996 to $2005 / 2006$. The authors found that the irrigated area increased 1.332.281 ha. Therefore, an increase of $42.7 \%$ in the irrigated area in the country was observed in about 10 years, which results in an average rhythm of 150 thousand hectares year ${ }^{-1}$. According to Luiz de Queiroz Foundation for Agricultural Studies (FEALQ, 2014), the Brazil has a potentially irrigable area of 61 million hectares. While it indicates a great 
potential of the country, these numbers highlight difficulties in the adoption of irrigation, either by the availability of land in regions without great climatic limitations to agriculture, or by the lack of knowledge of technicians and producers about the benefits of irrigated agriculture. The adoption of irrigation without technical knowledge usually results in low water productivity.

Considering what has been mentioned and discussed so far, the present study aimed to relate the information on water productivity drip and sprinkler irrigation systems, to facilitate the understanding of the characteristics of both systems and contribute to the advancement of studies and research conducted on these systems.

\section{Water Productivity}

Water productivity is a concept that aims to quantify the water unit return of in production of a crop (product unit per unit of water). Water productivity can be improved if it is possible to obtain the same amount of crop with less water, or increase the productivity of the crop by applying the same amount of water (MUSTAFA et al., 2008). In the field, this parameter has originally been represented in terms of $\mathrm{kg} \mathrm{m}^{-3}$, related, therefore, to the "efficiency" with which a crop uses water to generate its final product. Considering the rational use of water, the increase of water productivity in agriculture is a complex challenge, because it covers different strategies

Several factors affect water productivity, such as low soil fertility (MASIKATI et al., 2014), irrigation management (MARTIN et al., 2012) and irrigation system types (AHMAD et al., 2016). The great challenge is to increase crop productivity using less water as possible.

As a way of evaluating potential interventions in water productivity, several studies have been performed and deserve attention. Masikati et al. (2014) approached a modeling technique that uses the Agricultural Production Systems Simulator (SSPA), which is a model used to simulate complex climate, soil and vegetation management systems in maize and mucuna intercropping. This model was used to evaluate the long-term effects of maizemucuna rotations on smallholder farming systems in semi-arid areas of Zimbabwe, considering biomass production, grain yield, productivity, in the organic carbon dynamics and to investigate matter and total nitrogen in the soil, and to investigate the degree of stress due to water and nitrogen deficiency during the seasons. The authors concluded that the maizemucuna rotation system has the potential to improve maize productivity and soil fertility, and simulations have shown that water productivity is adversely and markedly affected by low soil fertility. Thus, it was observed that the average water productivity for grains of maize was $0.6 \mathrm{~kg} \mathrm{~m}^{-3}$, showing that there is scope for improving water productivity in small farms.

The technique of deficit irrigation has been the subject of a several researches that can assist in the water resources management. This technique has been employed as an alternative capable of increasing the efficiency of water use and has been used in low water availability situations. When evaluating the effect of different management strategies for deficit irrigation on the water productivity available to the maize crop for silage production, and their effects on silage productivity and quality, Martin et al. (2012) observed that the higher water productivity was obtained with deficit irrigation strategies.

Due to the necessity of increasing water use efficiency and productivity in agriculture, several studies have been performed aiming to evaluate these parameters in different crops, especially when applying drip or sprinkler irrigation, as shown in Table 1.

Table 1: Water productivity observed for different crops in several countries.

\begin{tabular}{cccccc}
\hline Author & Local & Crop & $\begin{array}{c}\text { Drip } \\
\text { Irrigation } \\
\text { System }\end{array}$ & $\begin{array}{c}\text { Sprinkler } \\
\text { Irrigation } \\
\text { System }\end{array}$ & $\begin{array}{c}\text { Water } \\
\text { Productivity } \\
\left.\mathbf{( k g ~ m}^{-3}\right)\end{array}$ \\
\hline (Yan; Wu, 2014) & China & $\begin{array}{c}\text { Winter wheat } \\
\text { (Triticum estivum L.) }\end{array}$ & & $\mathrm{X}$ & $0.7-1.4$ \\
\hline
\end{tabular}


Jesus et al.

\begin{tabular}{|c|c|c|c|c|c|}
\hline (Pejić et al., 2012) & Serbia & $\begin{array}{c}\text { Soybean } \\
\text { (Glycine max) }\end{array}$ & & $\mathrm{X}$ & 1.04 \\
\hline $\begin{array}{c}\text { (Feitosa et al., } \\
\text { 2016) }\end{array}$ & Brazil & $\begin{array}{c}\text { Papaya } \\
\text { (Carica papaya L.) }\end{array}$ & & $\mathrm{X}$ & 0.95 \\
\hline $\begin{array}{l}\text { (Lozano et al., } \\
\text { 2016) }\end{array}$ & Spain & $\begin{array}{c}\text { Strawberry } \\
\text { (Fragaria } \\
\text { Ananassa Duch cv. } \\
\text { Sabrina) } \\
\end{array}$ & $\mathrm{X}$ & & $16.5-18.3$ \\
\hline $\begin{array}{l}\text { (Lozano et al., } \\
\text { 2016) }\end{array}$ & Spain & $\begin{array}{c}\text { Strawberry } \\
\text { (Fragaria } \\
\text { Ananassa Duch cv. } \\
\text { Antilla) }\end{array}$ & $\mathrm{X}$ & & $13.8-14.3$ \\
\hline $\begin{array}{c}\text { (Fandika et al., } \\
\text { 2016) } \\
\end{array}$ & $\begin{array}{c}\text { New } \\
\text { Zealand }\end{array}$ & $\begin{array}{c}\text { Potato } \\
\text { (Solanum tuberosum) } \\
\end{array}$ & & $\mathrm{X}$ & 11.6 \\
\hline (Ati et al., 2016) & Iraq & $\begin{array}{c}\text { Potato } \\
\text { (Solanum tuberosum L.) } \\
\end{array}$ & $\mathrm{X}$ & & 10.25 \\
\hline (Souza et al., 2011) & Brazil & $\begin{array}{c}\text { Cowpea } \\
\text { (Vigna unguiculata L. cV. } \\
\text { Walp) }\end{array}$ & $\mathrm{X}$ & & 30.6 \\
\hline (Souza et al., 2011) & Brazil & $\begin{array}{c}\text { Maize } \\
\text { (Zea mays ssp.) }\end{array}$ & $\mathrm{X}$ & & 72.5 \\
\hline (Souza et al., 2014) & Brazil & $\begin{array}{c}\text { Fig } \\
\text { (Fícus carica L.) }\end{array}$ & $\mathrm{X}$ & & $1.65-3.32$ \\
\hline $\begin{array}{c}\text { (Phogat et al., } \\
\text { 2017) } \\
\end{array}$ & Australia & $\begin{array}{c}\text { Wine Grape } \\
\text { (Vitis labrusca L.ssp.) }\end{array}$ & $\mathrm{X}$ & & $11.16-13.46$ \\
\hline (Tari, 2016) & Turkey & $\begin{array}{c}\text { Wheat } \\
\text { (Triticum aestivum, L. ssp) }\end{array}$ & $\mathrm{X}$ & & $1.02-1.30$ \\
\hline $\begin{array}{l}\text { (Mantonvani et al., } \\
\text { 2013) }\end{array}$ & Brazil & $\begin{array}{c}\text { Sweet Potato } \\
\text { (Ipomoea batatas cv. } \\
\text { Amanda) }\end{array}$ & $\mathrm{X}$ & & 16.1 \\
\hline $\begin{array}{l}\text { (Valnir-Junior et } \\
\text { al., 2015) }\end{array}$ & Brazil & $\begin{array}{c}\text { Pepper } \\
\text { (Capsicum frutescens L., } \\
\text { cv. Tabasco) } \\
\end{array}$ & $\mathrm{X}$ & & 2.55 \\
\hline $\begin{array}{l}\text { (Mantonvani et al., } \\
\text { 2013) }\end{array}$ & Brazil & $\begin{array}{c}\text { Sweet Potato } \\
\text { (Ipomoea batatas cv. } \\
\text { Duda) }\end{array}$ & $\mathrm{X}$ & & 20 \\
\hline (Silva et al., 2013) & Brazil & $\begin{array}{c}\text { Tomato } \\
\text { (Lycopersicum esculentum } \\
\text { Mill) } \\
\end{array}$ & $\mathrm{X}$ & & 66.1 \\
\hline (Souza et al., 2011) & Brazil & $\begin{array}{c}\text { Bell pepper } \\
\text { (Capsicum annuum) }\end{array}$ & & $\mathrm{X}$ & 3.9 \\
\hline (Souza et al., 2012) & Brazil & $\begin{array}{c}\text { Pineapple } \\
\text { (Ananas comosus L. } \\
\text { Merrill) } \\
\end{array}$ & $\mathrm{X}$ & & 21.84 \\
\hline $\begin{array}{c}\text { (Teófilo et al., } \\
\text { 2012) }\end{array}$ & Brazil & $\begin{array}{c}\text { Melon } \\
\text { (Cucumis melo) }\end{array}$ & $\mathrm{X}$ & & 18.47 \\
\hline
\end{tabular}

New perspectives on efficient use and productivity of water in irrigated agriculture

The increasing demand for water multiple uses, especially for irrigation, increases the necessity of implementing crop water use efficiency experiments. In agriculture, water productivity can be improved through the use of strategies to increase productivity, such as the use of adequate inputs doses, the implementation of conservationist cultural practices, the implementation of techniques that reduce water losses (e.g. careful system adoption and irrigation management) and the application of strategies of storing water in the soil by increasing infiltration and reducing the rate of evaporation (TEÓFILO et al., 2012).

Maintaining soil covered with biomass, as in no-tillage, has been shown as a good noncosting practice for increasing water 
productivity. In a study on cabbage productivity, Carvalho et al. (2015) found that the use of mulching increased water productivity for this crop. The increase in water productivity due to soil cover was also observed by Teófilo et al. (2012) for melon culture. In this study, the authors showed higher total yield of the crop by the amount of water used in the growing conditions with soil covered with polyethylene film and with straw.

Research on the use of remote sensing as a tool to quantify water productivity on a large scale have been carried out in recent decades in order to support policy planning and decision making on natural resources uses (Teixeira et al., 2013; ZWART et al., 2010). From satellite imagery (thermal band) and meteorological data, actual evapotranspiration and crop biomass production can be estimated.

Large-scale water productivity was evaluated by Teixeira et al. (2013) in two Brazilian semi-arid cities, Petrolina-PE and Juazeiro-BA. The authors quantified the contrast between natural vegetation and irrigated crops using MODIS (Moderate Resolution Imaging Spectroradiometer) images and agrometeorological data, algorithm and radiation model to estimate the components of water productivity (biomass and evapotranspiration) for modeling in each city. The results obtained showed that the most frequent values of water productivity in Petrolina were between 1.6 and $2.2 \mathrm{~kg} \mathrm{~m}^{-3}$, and in Juazeiro were 1.0 to $1.6 \mathrm{~kg} \mathrm{~m}^{-3}$, which can be explained, according to the authors, by the uneven distribution of rainfall and the storage of water in the soil in each region. It was also observed that the natural vegetation presented greater spatial uniformity of the water productivity when compared to the irrigated crops. This result is extremely relevant because it allows to conclude that the proper management of irrigation can increase the water productivity of irrigated crops, demonstrating the importance of precision irrigation.

With the need to promote a higher efficient use of water in agriculture, new techniques and new irrigation equipments have been developed in recent years. For example,
Mobile Drip Irrigation (MDI) systems allow the joining of two types of systems: center pivot and drip irrigation systems (Figure 1). The system consists of an aerial lateral line (pivot), whose water outlets are coupled to descent tubes, similar to the lines of diversion (drip), and the drip tubes are dragged by the area as a function of the movement of the pivot Central (CRAIG, 2015; DERBALA, 2003).

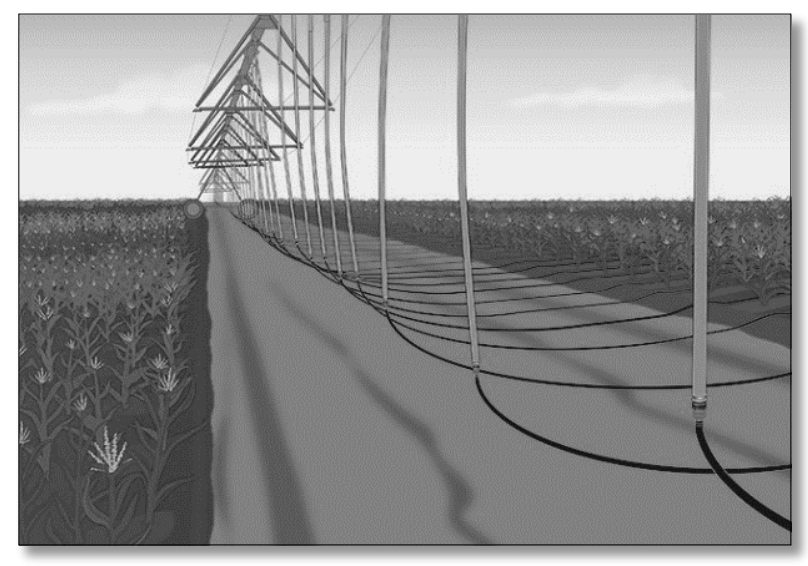

Figure 1. Mobile drip irrigation system (MDI) Source:

www.netafimusa.com/agriculture/products/hwdripperline /precision-mobile-drip-irrigation

Derbala (2003) states that this hybrid system is a way of associating the advantages of drip irrigation with the advantages of the center pivot. The earliest researches on this system were made in Fresno, California. According to Hezarjaribi and Sourell (2011), this hybrid system can reduce water and energy consumption by $20 \%$ and $70 \%$, respectively, when compared to a center pivot system. Some advantages of this hybrid system are described by Craig (2015) and Derbala (2003): irrigation efficiency can be greater than 95\%; allows to maintain irrigation even in freezing conditions; reduces or eliminates pivot skid problems, as the ground is always dry on the track of the wheels; energy savings compared to pivot and stationary drip; and allows the use in a center pivot system already installed. On the other hand, the main limitation of this system is the need to filter the water, which must be very efficient, using at least 80 mesh filters (CRAIG, 2015).

Another technique developed for the efficient use of water in irrigation is the 
application of water at variable rate. It is a recent technology incorporated into the center pivot system. For Dukes and Perry (2006), the center pivot irrigation system adapts well to variable rate irrigation if the equipment is changed with an individual sprinkler control system. However, it is important to emphasize the fundamental importance of agronomic and edaphoclimatic aspects related to irrigation automation, because there is no justification in adopting these automated resources without prior and adequate knowledge of the parameters necessary for promoting an efficient irrigation control. Thus, the investment in this technology should be understood as a means of reducing costs, and its technical and economic viability must be considered in each case.

\section{FINAL CONSIDERATIONS}

Technological innovations aiming to reduce water demand and increasing water productivity through improved water management have had limited impact and still need to be adopted on a large scale. It should be noted that future studies should focus on research to strengthen water-income relationships to improve productivity. In addition, technologies to be deployed in the field must be preceded by a cost analysis for each specific situation in order to verify the economic viability of the project.

\section{REFERENCES}

ATI, A. S.; IYADA, A. D.; NAJIM, S. M. Water use efficiency of potato (Solanum tuberosum L.) under different irrigation methods and potassium fertilizer rates. Annals of Agricultural Sciences, v. 57, n. 2, p. 99-103, 2012.

CARVALHO, L. C. C.; COELHO, R. D.; TEIXEIRA, M. B.; SOARES, F. A. L.; SILVA, N. F. Desempenho de gotejadores autocompensantes submetidos a aplicação de solução concentrada de ferro e carga orgânica.
Revista Brasileira de Agricultura IrrigadaRBAI, v. 9, n. 6, p. 366-375, 2015.

COELHO, R. D.; SANTOS JÚNIOR J. L.; MENDOZA, C. J.; RIBEIRO, P. H.; CUNHA, F. N.; TEIXEIRA, M. B. Efeito da aplicação de vácuo no desempenho de diferentes modelos de gotejadores sob duas condições de textura de solo. Revista Brasileira de Engenharia Agrícola e Ambiental, v. 17, n. 9, p. 909-917, 2013.

CRAIG, J. PMDI: Precision Mobile Drip Irrigation. Disponível em: $<$ http://www.depts.ttu.edu/tawc/documents/201 5FD/PMDI.pdf. $>$ Acesso em: 03 jan. 2017.

DERBALA, A. Development and evaluation of mobile drip irrigation with center pivot machine. In: Proceedings $8^{\text {th }}$ International Congress on Mechanization and Energy in Agriculture, Kuşadası, Turkey, 15-17 October 2002. Edge University, Faculty of Agriculture, p. 290-296, 2003.

DUKES, M.D., PERRY, C. Uniformity testing of variable-rate center pivot irrigation control systems. Precision Agriculture, v.7, n.3, p.205-218, 2006.

EMBRAPA. Embrapa Milho e Sorgo. Sistema de Produção, 1. ISSN 1679-012X Versão Eletrônica - 6a edição, Set./2010. Dispo nível em: <

https://ainfo.cnptia.embrapa.br/digital/bitstream /item/27037/1/Plantio.pdf $>$. Acesso em: 03 jan. 2017.

FANDIKA, I. R.; KEMP, P. D.; MILLNER, J. P.; HORNE, D.; ROSKRUGE, N. Irrigation and nitrogen effects on tuber yield and water use efficiency of heritage and modern potato cultivars. Agricultural Water Management, v. 170, p. 148-157, 2016.

FEITOSA, E. O.; ARAÚJO, A. F. B.; OLIVEIRA, C. M. B.; LOPES, F. B.; ANDRADRE, E. M Irrigation productivity and water-use efficiency in papaya crop under semi- 

SPRINKLER SYSTEMS

arid conditions. African Journal of Agricultural Research, v. 11, n. 42, p. 41814188, 2016.

HOWELL, T.A., 1990. Relationships between crop production and transpiration, evapotranspiration, and irrigation. In: Stewart, B.A., Nielsen, D.R. (Eds.), Irrigation of Agricultural Crops, Agronomic Monograph 30. ASA, CSSA, SSSA, Madison, WI, USA, p. 391-434.

KELLER, A., SECKLER, D. Limits to increasing the productivity of water in crop production. California Water Plan Update 4, p. 178-197, 2005.

LACERDA, N.B.; OLIVEIRA, T.S. Agricultura irrigada e a qualidade de vida dos agricultores em perímetros do Estado do Ceará. Revista Ciência Agronômica, v.38, n. 2, p. 216-223, 2007.

LOZANO, D.; RUIZ, N.; GAVILÁN, P. Consumptive water use and irrigation performance of strawberries. Agricultural Water Management, v. 169, p. 44-51, 2016.

MARTIN, J. D.; CARLESSO, R.; AIRES, N. P.; GATTO, J. C.; DUBOU, V.; FRIES, H. M.; SCHEIBLER, R. B. Irrigação deficitária para aumentar a produtividade da água na produção de silagem de milho. Irriga, Edição Especial, p. 192 - 205, 2012.

MASIKATI, P., MANSCHADI, A, VAN ROOYEN, A., HARGREAVES, J. Maize mucuna rotation: An alternative technology to improve water productivity in smallholder farming systems. Agricultural Systems, v. 123, p. 62-70, 2014.

MUSTAFA, Y., GRANDO, S., MAATOUGUI, M. Optimal agronomic practices to improve water productivity for barley in Highlands of Eritrea. In: Paper Presented at the CPWF Workshop on Increasing Water Productivity of Rainfed Cropping Systems. Tamale, Gana, 2008.
PAULINO, J.; FOLEGATTI, M. V.; ZOLIN, C. A.; ROMÁN, R. M. S.; JOSÉ, J. V. Situação da agricultura irrigada no brasil de acordo com o censo agropecuário 2006. Irriga, v. 16, n. 2, p. 163-176, 2011.

PEJIĆ, B.; MAHESHWARI, B.; ŠEREMEŠIĆ, S.; STRIČEVIĆ, R.; PACUREANU-JOITA, M.; RAJIĆ, M.; ĆUPINA, B. Water-yield relations of maize (Zea mays L.) in temperate climatic conditions. Maydica, v. 56, n. 4, 2012.

PERRY, C. Accounting for water use: Terminology and implications for saving water and increasing production. Agricultural Water Management, v. 98, n. 12, p. 1840-1846, 2011. PERRY, C. Efficient irrigation; inefficient communication; flawed recommendations. Irrigation and drainage, v. 56, n. 4, p. 367-378, 2007.

PERRY, C.; STEDUTO, P.; ALLEN, R. G.; BURT, C. M. Increasing productivity in irrigated agriculture: agronomic constraints and hydrological realities. Agricultural Water Management, v. 96, n. 11, p. 1517-1524, 2009.

PHOGAT, V.; SKEWES, M. A.; MCCARTHY, M. G.; COX, J. W.; ŠIMŮNEK, J.; PETRIE, P. R. Evaluation of crop coefficients, water productivity, and water balance components for wine grapes irrigated at different deficit levels by a sub-surface drip. Agricultural Water Management, v. 180, p. 22-34, 2017.

SILVA, J. M.; FERREIRA, R. S.; MELO, A. S.; SUASSUNA, J. F.; DUTRA, A. F.; GOMES, J. P. Cultivo do tomateiro em ambiente protegido sob diferentes taxas de reposição da evapotranspiração. Revista Brasileira de Engenharia Agrícola e Ambiental, v. 17, n. 1, p. 40-46, 2013.

SOUZA, A. P. D.; SILVA, A. C. D.; LEONEL, S.; SOUZA, M. E. D.; TANAKA, A. A. Evapotranspiração e eficiência do uso da água no primeiro ciclo produtivo da figueira 'Roxo de valinhos' submetida a cobertura morta. Bioscience Journal, v. 30, n. 4, p. 1127-1138, 2014. 
SOUZA, A. P.; PEREIRA, J. B. A.; SILVA, L. D. B.; GUERRA, J. G. M.; CARVALHO, D. F. Evapotranspiração, coeficientes de cultivo e eficiência do uso da água da cultura do pimentão em diferentes sistemas de cultivo. Acta Scientiarum Agronomy, v. 33, n. 1, p. 15-22, 2011b.

SOUZA, L. D.; MOURA, M. D.; SEDIYAMA, G. C.; SILVA, T. D. Eficiência do uso da água das culturas do milho e do feijão-caupi sob sistemas de plantio exclusivo e consorciado no semiárido brasileiro. Bragantia, v. 70, n. 3, p. 715-721, 2011a.

SOUZA, O. P.; ZANINI, J. R.; TORRES, J. L. R.; BARRETO, A. C.; SOUZA, E. L. C. Produção e qualidade física dos frutos do abacaxi sob diferentes lâminas e frequências de irrigação. Irriga, v. 17, n. 4, p. 534, 2012.

SOUZA, W. D. J.; BOTREL, T. A.; COELHO, R. D.; NOVA, N. A. Irrigação localizada subsuperficial: Gotejador convencional e novo protótipo. Revista Brasileira de Engenharia Agrícola e Ambiental, v. 16, n. 8, p. 811-819, 2012.

TARI, A. F. The effects of different deficit irrigation strategies on yield, quality, and wateruse efficiencies of wheat under semi-arid conditions. Agricultural Water Management, v. 167, p. 1-10, 2016.

TEIXEIRA, A. H. C.; SCHERER-WARREN, M.; HERNANDEZ, F. B.; ANDRADE, R. G.; LEIVAS, J. F. Large-scale water productivity assessments with MODIS images in a changing semi-arid environment: A Brazilian case study. Remote Sensing, v. 5, n. 11, p. 5783-5804, 2013.

TEÓFILO, T. D. S.; FREITAS, F. C. L.; MEDEIROS, J. D.; SILVA, D. D.; GRANGEIRO, L. C.; TOMAZ, H. D. Q. Eficiência no uso da água e interferência de plantas daninhas no meloeiro cultivado nos sistemas de plantio direto e convencional. Planta daninha, v. 30, n. 3, p. 547-556, 2012.

VIEIRA, G. H. S.; MANTOVANI, E. C.; SOARES, A. A.; MONTES, D. R. P.; CUNHA, F. F. Custo da irrigação do cafeeiro em diferentes tipos de equipamento e tamanhos de área. Engenharia na agricultura, v. 19, n. 1, p. 53-61, 2011.

YAN, N.; WU, B. Integrated spatial-temporal analysis of crop water productivity of winter wheat in Hai Basin. Agricultural Water Management, v. 133, p. 24-33, 2014.

ZWART, S. J.; BASTIAANSSEN, W. G. Review of measured crop water productivity values for irrigated wheat, rice, cotton and maize. Agricultural Water Management, v. 69, n. 2, p. 115-133, 2004.

ZWART, S. J.; BASTIAANSSEN, W. G.; FRAITURE, C.; MOLDEN, D. J. WATPRO: a remote sensing based model for mapping water productivity of wheat. Agricultural Water Manage, v. 97, p.1628-1636, 2010. 